\title{
Macrobenthos of the coastal Budi Lagoon, southern Chile: Changes associated with seasonal environmental variation
}

\author{
Carlos Bertrán ${ }^{1}$, Pablo Fierro ${ }^{1}$,Elizabeth Encalada ${ }^{1}$,Fernando Peña-Cortés ${ }^{2}$, Jaime Tapia ${ }^{3}$, \\ Enrique Hauenstein ${ }^{4}$, Luis Vargas-Chacoff ${ }^{1,5 *}$
}

\author{
${ }^{1}$ Institute of Marine Science and Limnology, Universidad Austral de Chile, Chile. \\ ${ }^{2}$ Territorial Planning Laboratory, Universidad Católica de Temuco, Chile \\ ${ }^{3}$ Institute of Chemistry and Natural Resources, Universidad de Talca, Chile \\ ${ }^{4}$ Faculty of Sciences, Universidad Católica de Temuco, Temuco, Chile. \\ ${ }^{5}$ Centro Fondap de Investigación de Altas Latitudes (IDEAL), Universidad Austral de Chile, Valdivia, Chile. \\ *Corresponding author: luis.vargas@uach.cl \\ Financial Support: This study was possible due to the support of FONDECYT projects 1110798 and 1151375.
}

\section{Abstract}

The purpose of the present study was to investigate the seasonal relationship of macrobenthos richness and abundance with sediment characteristics (i.e. texture and organic material) for the coastal Budi Lagoon in southern Chile. Physicochemical measurements and macrobenthos samples were taken over the course of a year at nine sampling stations. Sandy-muddy sediment was the most common, and high percentages of organic material were registered, varying significantly between seasons and stations. The recorded organic material was related to natural (resident wild birds) and anthropogenic (agriculture) sources. Regarding fauna, 28 benthonic taxa and 7092 individuals were identified, with temporal and spatial variations. The most abundant taxa year-round were the molluscs Littoridina cumingii and Kingiella chilenica and the bristle worm Prionospio patagonica. Together, the obtained results evidence the important impact of organic material on the macrobenthos, with macrobenthic richness and abundance decreasing in conditions of high organic material content. The recorded variations for different taxa may indicate a response to the land use around the Budi Lagoon, which is intensely subjected to agricultural and tourist activities.

Descriptors: Macrobenthos, Budi Lagoon, Araucania, Sediments, Spatial variability.

\section{RESUMo}

O objetivo do presente estudo foi investigar a relação sazonal entre macrobentos $\mathrm{e}$ características do sedimento, tais como textura e material orgânico, na lagoa costeira Budi Lagoon, sul do Chile. Medidas físico-químicas e amostragem do macrobentos foram realizadas durante um ano em nove localidades. Sedimento arenoso-lodoso foi o mais comum na lagoa, e percentagens elevadas de material orgânico foram registradas, variando significativamente entre as estações e locais de coleta. Em relação a fauna, foram identificados 28 taxas bentônicos e 7092 indivíduos, que apresentaram variação temporal e espacial. As espécies mais abundantes durante todo o ano foram os moluscos Littoridina cumingii e Kingiella chilenica, e o poliqueta Prionospio patagonica. Os resultados obtidos evidenciaram o importante impacto da matéria orgânica sobre o macrobentos, com riqueza e abundância da fauna diminuindo em presença de alto teor de matéria. As variações encontradas para os diferentes taxons indicaram resposta da fauna ao uso da terra ao redor de Budi Lagoon, que intensamente utilizada para agricultura e atividades turísticas.

Descritores: Macrobentos, Budi Lagoon, Araucanía, Sedimentos, Variabilidade espacial. 


\section{INTRODUCTION}

Most animal populations show considerable spatial and temporal fluctuations in distribution and abundance (UNDERWOOD; CHAPMAN, 1996; BENEDETTICECCHI et al., 2001; BERTRÁN et al., 2001; FIERRO et al., 2014; FIERRO et al., 2015). In the case of benthic macrofauna, distribution and abundance are mainly related to certain variables of the sedimentwater interface, where multiple effects of contamination and organic enrichment are exerted (GLÉMAREC, 1986). The principal physicochemical variables that determine macrobenthic distribution are temperature, salinity, suspended solids, nitrates (HOLLAND et al., 1987; BEUKEMA, 1990; FIERRO et al., 2015), and sediment characteristics, such as texture and organic material content (RITCHER, 1985; NICHOLS et al., 1986). Macrobenthic organisms inhabit different types of sediments (HYNES, 1970) over the course of the year (BERTRÁN, 1989; BERTRÁN et al., 2001; FIERRO et al., 2012), generating varied distribution and abundance patterns (JARAMILLO et al., 2001).

The distribution of the macrobenthos has possible application in estimating the spatial and temporal variations of different ecosystems, such as coastal lakes and estuaries. Lagoons are a non-continental, transitional ecosystem temporally influenced by seawater (KJERFVE, 1994; PÉREZ-RUZAFA et al., 2011). The entrance of high-salinity water into lagoons sufficiently sustains fauna with estuarine traits (DÍAZJARAMILLO et al., 2008). Additionally, lagoons and estuaries both present high environmental variability, leading some authors to consider both as a single ecosystem unit (STUARDO; VALDOVINOS, 1989; BERTRÁN et al., 2010).

One such ecosystem unit is the Budi Lagoon, where the periodic entrance of seawater largely and seasonally modifies water parameters (BERTRÁN et al., 2010). Furthermore, the permanent presence of aquatic birds and anthropic activity in the watershed, particularly near the shoreline, means that this lagoon is constantly incorporating organic material (PEÑACORTÉS et al., 2006a; 2006b, 2011). The objective of this study was to explore the relationship between seasonal variations in benthic macrofauna communities and fluctuations in water characteristics of the coastal Budi Lagoon, including sediment texture and organic material content.

\section{MATERIAL AND METHODS}

\section{STUDY SITE}

The Budi Lagoon (3849'30' S, 73²3'30” W) begins about one mile south of the Imperial River estuary in southern Chile. The Budi Lagoon sporadically connects with the Pacific Ocean, specifically from the end of autumn until the beginning of spring. This lagoon has a surface area of $57.4 \mathrm{~km}^{2}$, and its basin has a dry coastal landscape that is highly fragmented by anthropogenic activities, with native oak-laurel-lingue and temo-pitra forests (BERTRÁN et al., 2006; 2010).

\section{SAMPLING AND ANALYTICAL METHOD}

Sampling was performed in 2005 during each of the four seasons at nine sampling stations: Budi River (E1), Temo (E2), Deume 1 (E3), Deume 2 (E4), Deume 3 (E5), Comue (E6), Bolleco (E7), Allipen (E8), and Botapulli (E9) (Figure 1). At each station, water was sampled using a Ruhtner bottle, and the temperature and salinity of the bottom layer was measured. Sediment samples (5 replicates per station) were also collected using an Emery Dredge $\left(0.25 \mathrm{~m}^{2}\right)$ to sample the macrobenthos, characterize sediment texture (FOLK, 1980), and determine organic material (BYERS et al., 1978). Macrobenthos samples were sieved through a $0.5 \mathrm{~mm}$ mesh, fixed in $10 \%$ formalin, transported to the Bentos Laboratory of the Universidad Austral de Chile, and preserved in $70 \%$ ethanol. In the laboratory, samples were examined under a stereoscopic microscope, and taxa were identified to the lowest possible taxonomic level using specialized literature.

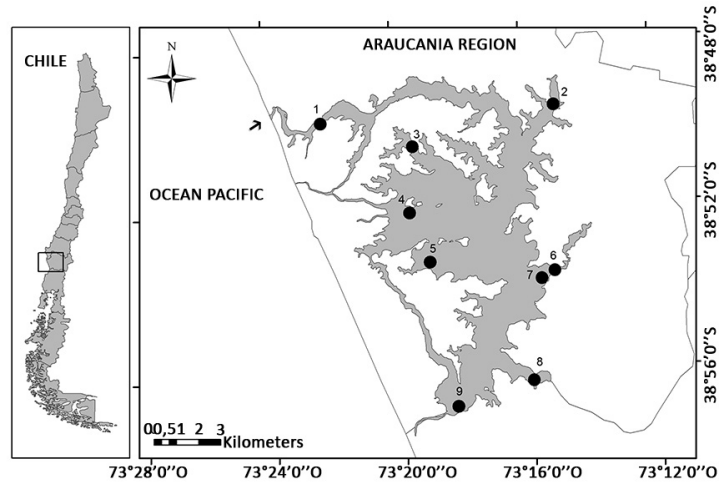

Figure 1. Location of the Budi Lagoon and sampling stations (black circle). Arrow indicates connection between the lagoon and sea. 


\section{STATISTICAL ANALYSIS}

The community structure of the Budi Lagoon macrobenthos was described for each site and season based on the following indexes: Number of taxa, Abundance, and Shannon-Wiener diversity $\left(H^{\prime}\right)$, following BROWER et al. (1990). Community structure and organic material were analysed using non-metric multidimensional scaling analysis as the ordination method, and similitude between sampling stations was based on a similarity matrix constructed using the Bray-Curtis similarity index. This analysis was performed in PRIMER v.6 (Plymouth Routines in Multivariate Ecological Research) (CLARKE et al., 2005).

For the variables that fulfilled assumptions of normality, independence, and homoscedasticity, a two-way ANOVA was performed. In all cases, the two factors were space (sampling stations) and time (season). Sediment values were first arcsine transformed. Since abundances were non-parametric, this variable was assessed using the Kruskal-Wallis test. Significant differences $(p<0.05)$ were further analysed using the Tukey's HSD a posteriori test.

\section{RESULTS}

\section{PHYSICOCHEMICAL CHARACTERISTICS}

The water temperature of the lagoon bottom varied from $10{ }^{\circ} \mathrm{C}$ (autumn and winter) to $15{ }^{\circ} \mathrm{C}$ (spring) and 21 ${ }^{\circ} \mathrm{C}$ (summer), following a seasonal cycle with maximum temperatures in the summer and minimums in the winter. The lowest values of salinity were measured in winterspring $(1.7 \%)$, and the highest values were in the summer $(2.66 \%)$ and autumn $(4.2 \%)$.

\section{SEDIMENT CHARACTERISTICS}

Sandy-muddy sediment was the most common in the lagoon. The highest percentage of sand was registered in station E8 (97\% in winter and autumn), while mud was the most abundant at station E2 (87\% in spring). Gravel sediment was the least common, with the highest percentages registered at stations E5 (18.3\% in autumn) and E7 (16.9\% in winter) (Table 1).

Organic material content significantly differed between seasons $(p<0.05)$. The highest seasonal mean was $23.5 \%$ (station E8 in spring), and the lowest seasonal means were $1.2 \%$ and $1.34 \%$ (stations E7 and E8 in winter, respectively). Considering all stations together, the highest mean organic content occurred in spring (13.2\%; Table 1).
To examine the patterns in organic material, nonmetric multidimensional scaling and cluster analyses were performed (Figure 2). During the summer, stations E9 and $\mathrm{E} 1$ were the most different from the other sampling stations; while in the autumn, stations E9 and E8 were the most different. In the winter, stations E7, E8, and E4 were the most different, but in spring, station E9 was once again the most different from all other stations.

\section{DESCRIPTION OF THE MACROBENTHOS COMMUNITY}

During the sampling period, a total of 28 taxa were recorded: Polychaeta (4), Gastropoda (3), Oligochaeta (1), Bivalvia (3), Amphipoda (1), Isopoda (2), Ostracoda (1), Nematoda (1), Nemertinea (1), Platyhelminthes (1) and Insecta (10) (Table 2). A total of 7092 individuals were sampled, of which, the most frequent taxon was the Mollusca phylum (47.14\%, 3343 individuals), followed by Annelida (40.65\%, 2883 individuals). Together, these taxons constituted more than $80 \%$ of the macrobenthos (Table 2). The most abundant mollusc was the gastropod Littoridina cumingii, especially in the winter at stations E4 (588 ind. $\mathrm{m}^{-2}$ ) and E8 (695 ind. $\mathrm{m}^{-2}$ ). Other abundant molluscs included the bivalve Kingiella chilenica, particularly at station E5 in the autumn (413 ind. $\left.\mathrm{m}^{-2}\right)$. The most abundant annelid species was Prionospio patagonica (Spionidae), which was present at all stations during all seasons, with the greatest abundance of this species recorded at station E7 in the spring (798 ind. $\mathrm{m}^{-2}$; Table 2). There were considerable increases in abundance between seasons, especially at station E5 (1482 total individuals). The opposite tendency was found at stations E3 and E2, which were significantly different from the rest of the stations (Figure 3). Specifically, the total individuals sampled at these stations over the year were 24 and 187 individuals, respectively (Table 2).

There was a significant difference between the total abundances recorded in different seasons $(p<0.05)$. The greatest total abundance was found in autumn (2375 ind. $\mathrm{m}^{-2}$ ), and the lowest abundance was recorded in summer (1196 ind. $\mathrm{m}^{-2}$ ). The season-station interaction was also significant $(p<0.05)$. The greatest abundances were found at stations E5 in the autumn, E7 in the spring, E8 in the winter, and E9 in the summer (Figure 4A). The non-metric multidimensional scaling analysis cluster analyses (Figure 3) separated station E3 from the rest of the sampling stations in all seasons, a result due mainly to the low abundance of macrobenthic organisms at this station. 
Table 1. Mean percentage ( \pm SD) of sediment textures (i.e. Gravel, Sandy, and Muddy) and organic material (Org. Mat.) recorded at the nine Budi Lagoon sampling stations.

\begin{tabular}{|c|c|c|c|c|c|c|c|c|c|c|c|c|c|}
\hline \multirow{3}{*}{$\overline{E 1}$} & \multirow[b]{3}{*}{ Gravel } & \multicolumn{3}{|c|}{ Summer } & \multicolumn{3}{|c|}{ Winter } & \multicolumn{3}{|c|}{ Autumn } & \multicolumn{3}{|c|}{ Spring } \\
\hline & & \multicolumn{2}{|l|}{ Average } & \multirow{2}{*}{$\begin{array}{l}\text { SD } \\
0.6\end{array}$} & \multirow{2}{*}{$\begin{array}{c}\text { Average } \\
0.3\end{array}$} & \multirow[b]{2}{*}{ \pm} & \multirow{2}{*}{$\begin{array}{l}\text { SD } \\
0.1\end{array}$} & \multicolumn{2}{|l|}{ Average } & \multirow{2}{*}{$\begin{array}{l}\text { SD } \\
0.8\end{array}$} & \multicolumn{2}{|l|}{ Average } & \multirow{2}{*}{$\begin{array}{l}\text { SD } \\
1.0\end{array}$} \\
\hline & & 0.9 & \pm & & & & & 0.6 & \pm & & 1.0 & \pm & \\
\hline & Sandy & 86.3 & \pm & 7.4 & 34.4 & \pm & 7.6 & 32.8 & \pm & 19.8 & 48.4 & \pm & 15.0 \\
\hline & Muddy & 12.8 & \pm & 7.0 & 65.4 & \pm & 7.6 & 66.6 & \pm & 20.1 & 50.6 & \pm & 15.0 \\
\hline & Org. Mat. & 2.5 & \pm & 1.0 & 8.1 & \pm & 0.2 & 7.7 & \pm & 0.9 & 6.9 & \pm & 1.5 \\
\hline \multirow[t]{4}{*}{ E2 } & Gravel & 0.5 & \pm & 0.6 & 0.2 & \pm & 0.2 & 1.3 & \pm & 0.8 & 0.8 & \pm & 1.0 \\
\hline & Sandy & 14.6 & \pm & 5.0 & 17.7 & \pm & 6.0 & 24.5 & \pm & 15.8 & 11.8 & \pm & 7.1 \\
\hline & Muddy & 84.9 & \pm & 5.0 & 82.1 & \pm & 6.1 & 74.3 & \pm & 15.1 & 87.4 & \pm & 6.8 \\
\hline & Org. Mat. & 16.1 & \pm & 0.5 & 14.8 & \pm & 2.1 & 17.2 & \pm & 2.1 & 17.7 & \pm & 0.4 \\
\hline \multirow[t]{4}{*}{ E3 } & Gravel & 1.3 & \pm & 2.0 & 0.6 & \pm & 0.4 & 0.7 & \pm & 0.5 & 0.4 & \pm & 0.6 \\
\hline & Sandy & 23.5 & \pm & 5.3 & 33.0 & \pm & 8.4 & 48.9 & \pm & 13.5 & 34.1 & \pm & 10.1 \\
\hline & Muddy & 75.2 & \pm & 4.8 & 66.3 & \pm & 8.5 & 50.5 & \pm & 13.2 & 65.5 & \pm & 10.2 \\
\hline & Org. Mat. & 19.7 & \pm & 0.5 & 19.1 & \pm & 2.6 & 22.6 & \pm & 1.1 & 19.1 & \pm & 1.0 \\
\hline \multirow[t]{4}{*}{ E4 } & Gravel & 1.5 & \pm & 0.7 & 3.6 & \pm & 3.5 & 10.5 & \pm & 5.1 & 2.4 & \pm & 1.6 \\
\hline & Sandy & 62.2 & \pm & 4.3 & 88.8 & \pm & 4.4 & 58.9 & \pm & 15.0 & 35.2 & \pm & 15.6 \\
\hline & Muddy & 36.3 & \pm & 4.6 & 7.6 & \pm & 2.1 & 30.6 & \pm & 19.6 & 62.4 & \pm & 15.5 \\
\hline & Org. Mat. & 20.1 & \pm & 1.9 & 1.9 & \pm & 0.3 & 5.5 & \pm & 2.1 & 5.2 & \pm & 1.1 \\
\hline \multirow[t]{4}{*}{ E5 } & Gravel & 10.1 & \pm & 18.5 & 1.6 & \pm & 0.6 & 18.3 & \pm & 15.6 & 1.2 & \pm & 1.8 \\
\hline & Sandy & 41.1 & \pm & 7.3 & 44.2 & \pm & 10.5 & 44.0 & \pm & 12.1 & 14.9 & \pm & 8.3 \\
\hline & Muddy & 48.8 & \pm & 22.6 & 54.3 & \pm & 10.9 & 37.8 & \pm & 18.4 & 83.9 & \pm & 8.4 \\
\hline & Org. Mat. & 14.8 & \pm & 1.2 & 14.6 & \pm & 1.0 & 15.9 & \pm & 4.3 & 16.0 & \pm & 0.4 \\
\hline \multirow[t]{4}{*}{ E6 } & Gravel & 1.8 & \pm & 1.7 & 0.5 & \pm & 0.4 & 12.8 & \pm & 7.1 & 4.9 & \pm & 7.2 \\
\hline & Sandy & 39.4 & \pm & 10.9 & 26.9 & \pm & 3.0 & 72.6 & \pm & 4.6 & 38.7 & \pm & 7.0 \\
\hline & Muddy & 58.7 & \pm & 12.0 & 72.6 & \pm & 2.8 & 14.6 & \pm & 7.9 & 56.4 & \pm & 10.9 \\
\hline & Org. Mat. & 12.6 & \pm & 3.2 & 12.1 & \pm & 1.4 & 4.8 & \pm & 2.5 & 11.9 & \pm & 1.4 \\
\hline \multirow[t]{4}{*}{ E7 } & Gravel & 7.5 & \pm & 7.8 & 16.9 & \pm & 3.7 & 0.3 & \pm & 0.2 & 6.9 & \pm & 2.7 \\
\hline & Sandy & 52.6 & \pm & 24.0 & 82.1 & \pm & 4.0 & 34.2 & \pm & 9.3 & 78.3 & \pm & 12.9 \\
\hline & Muddy & 39.9 & \pm & 17.1 & 1.1 & \pm & 0.6 & 65.5 & \pm & 9.4 & 14.8 & \pm & 15.0 \\
\hline & Org. Mat. & 12.7 & \pm & 3.1 & 1.2 & \pm & 0.2 & 10.7 & \pm & 1.3 & 5.4 & \pm & 2.8 \\
\hline \multirow[t]{4}{*}{ E8 } & Gravel & 1.6 & \pm & 2.7 & 0.4 & \pm & 0.2 & 0.1 & \pm & 0.1 & 1.5 & \pm & 1.9 \\
\hline & Sandy & 15.5 & \pm & 7.0 & 97.1 & \pm & 1.2 & 96.6 & \pm & 1.3 & 28.8 & \pm & 11.1 \\
\hline & Muddy & 83.0 & \pm & 7.0 & 2.5 & \pm & 1.3 & 3.3 & \pm & 1.4 & 69.7 & \pm & 12.4 \\
\hline & Org. Mat. & 18.6 & \pm & 1.5 & 1.3 & \pm & 1.4 & 1.8 & \pm & 0.2 & 23.5 & \pm & 6.8 \\
\hline \multirow[t]{4}{*}{ E9 } & Gravel & 0.2 & \pm & 0.1 & 2.0 & \pm & 0.8 & 5.8 & \pm & 3.0 & 0.8 & \pm & 0.8 \\
\hline & Sandy & 96.5 & \pm & 1.8 & 38.0 & \pm & 5.9 & 90.3 & \pm & 2.9 & 95.7 & \pm & 1.6 \\
\hline & Muddy & 3.3 & \pm & 1.9 & 60.0 & \pm & 5.7 & 3.9 & \pm & 0.7 & 3.5 & \pm & 2.0 \\
\hline & Org. Mat. & 1.6 & \pm & 1.0 & 18.4 & \pm & 1.6 & 2.8 & \pm & 0.7 & 1.5 & \pm & 0.3 \\
\hline
\end{tabular}

\section{COMMUNITY PARAMETERS}

The greatest species richness was found in autumn, especially at station E8, where 12 species were recorded. Among the sampling stations, station E3 had the lowest number of species during all seasons.
There were significant differences in diversity for stations E3 and E1. Station E3 was different from all other stations, while station E1 was different from stations E3, E5, and E6. Diversity in the spring and summer was greater than in the autumn and winter. The highest diversity values were found in the summer and ranged from 0.89 to 2.37 (Figure 4B, C, D). 


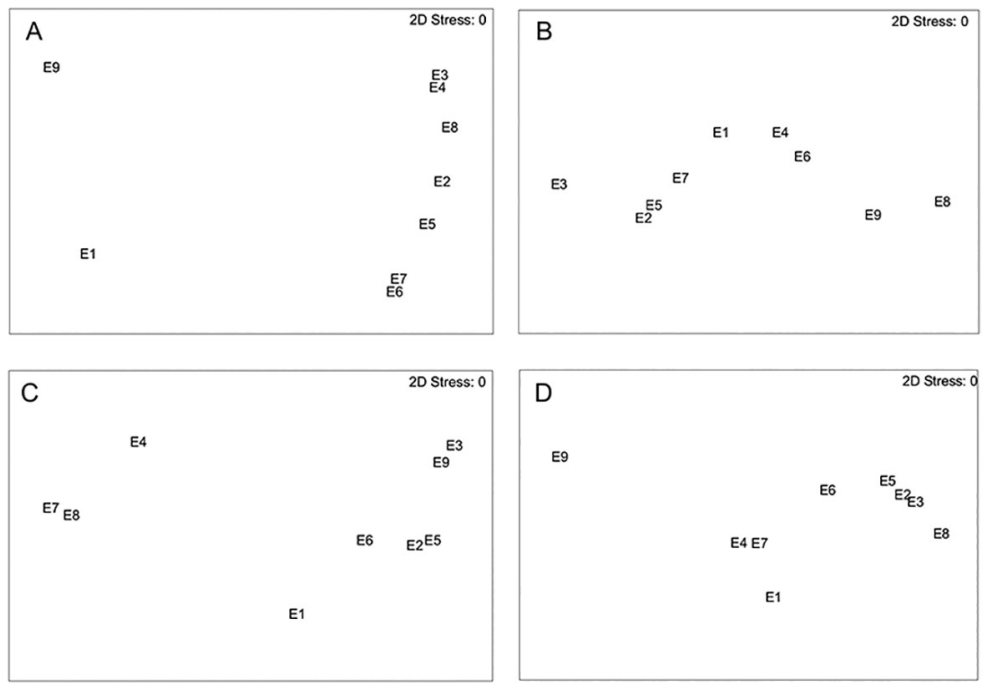

Figure 2. Non-metric multidimensional scaling ordination plot for Budi Lagoon organic material calculated for the four seasons of 2005 (A: summer, B: autumn, C: winter, D: spring).

\section{DISCUSSION}

The high amount of organic material found in the sediment of the Budi Lagoon is due to its semi-closed condition and the large amount of nutrients that enter the lagoon via agricultural runoff from the adjacent town (PEÑA-CORTÉS et al., 2006a;b) and from resident wild birds (BERTRÁN et al., 2010). Indeed, more than 10,000 birds were registered in a 2014 census of the lagoon area. The levels of organic material at Budi Lagoon were quite high compared to the lower levels of other aquatic ecosystems, such as the lagoon in the Cádiz Bay, Spain (DRAKE; ARIAS, 1997), the lower course of the Biobio River, Chile (BERTRÁN et al., 2001), and the estuary of the Queule River, Chile (JARAMILLO et al., 1984).

The temporal variations in organic material and texture characteristics of the sediment were similar to patterns of variation found in other studies, where. For example, the Queule River (QUIJÓN; JARAMILLO, 1993) and Biobio River (BERTRÁN et al., 2001), similar to the Budi Lagoon, registered a predominance of sand and less organic material in winter while summer was predominated by fine sediment and high organic contents. These seasonal fluctuations in texture and organic content at the Budi Lagoon may be due mainly to the input of biogenic and terrigenous material produced by intense precipitations, which, during 2005 , occurred in autumn and winter, particularly between May and August (DGAC, 2006). In turn, the summer months lacked rain, a situation that has been associated with greater deposition and, consequently, increased organic material (BERTRÁN et al., 2001).

The observed macrobenthic richness of the Budi Lagoon was similar to that described for other coastal lakes, lagoons, and estuaries (STONER; ACEVEDO, 1990; BERTRÁN et al., 2001; SFRISO et al., 2001; PEQUEÑO et al., 2010; FIERRO et al., 2014), showing relatively low density and high dominance (MISTRI et al., 2001; BERTRÁN et al., 2013). The Budi Lagoon macrobenthos increased in abundance in the autumn, similar to findings in other soft-bottom ecosystems, such as the estuary of the Berg River, South Africa (KALEJTA; HOCKEY, 1991) and the Cádiz Bay (ARIAS; DRAKE, 1994), where abundance was greatest in the spring, closely followed by autumn. These patterns were also comparable to those of rivers near the study area, with FIERRO et al. (2015) reporting the highest abundance of macroinvertebrates in the summer-autumn. This tendency could represent transitional periods related to increased primary production in the summer and the increased precipitation, decreased salinity, and increased re-suspension of deposited materials as a consequence of forceful winds in the winter. The increases in abundance may also be related to reproductive and recruitment periods, which normally occur in the summer and autumn (GALLARDO, 1993; CONTRERAS et al., 2003). Notably, the diversity and species richness values recorded in these seasons mainly corresponded to immature insects.

The temporal variation of the macrobenthos showed differences compared to reports for estuaries (BERTRÁN et 
Bertrán et al.: Variation in Budi Lagoon macrobenthos

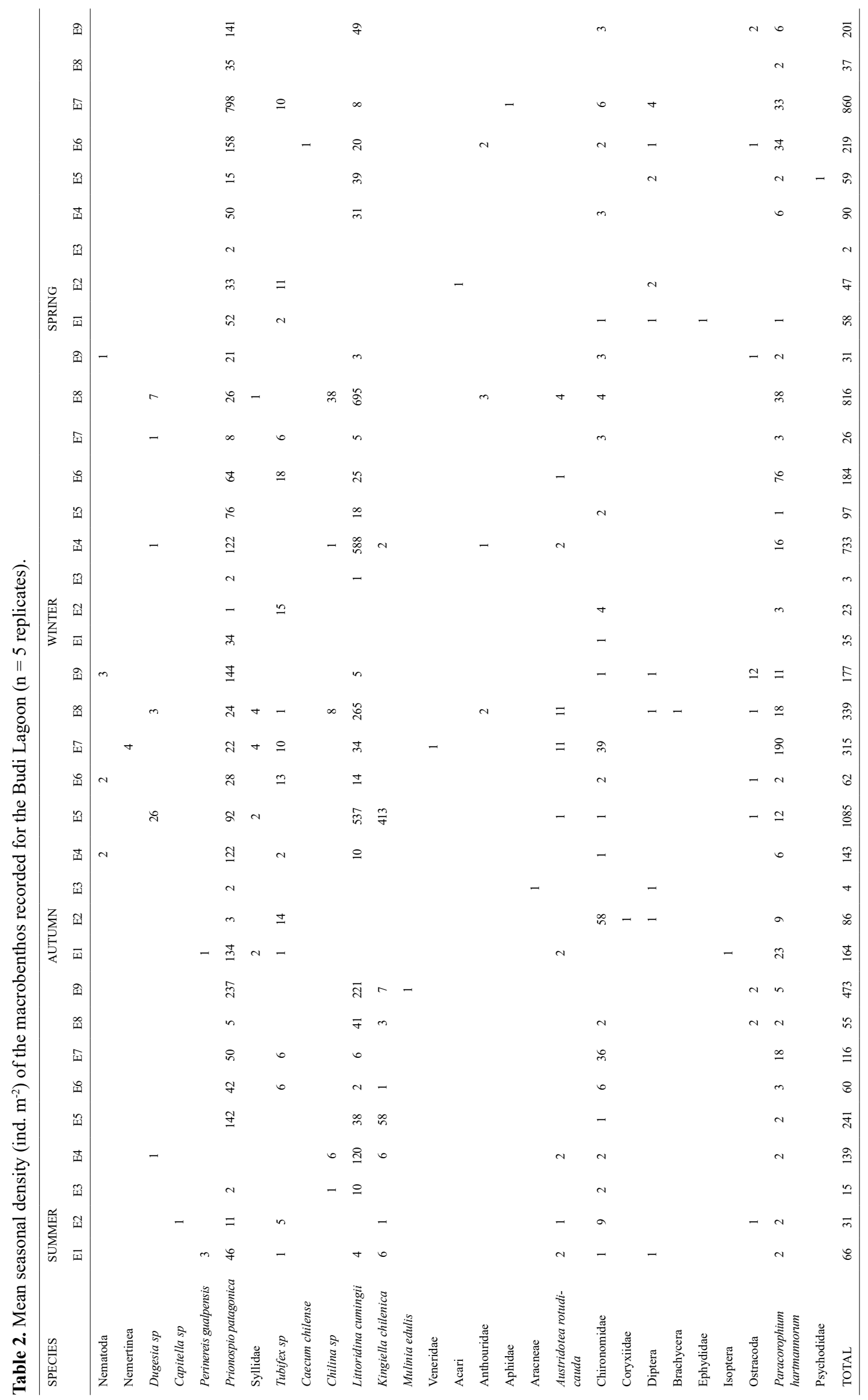

244

BRAZILIAN JOURNAL OF OCEANOGRAPHY, 64(3):239-248;2016 


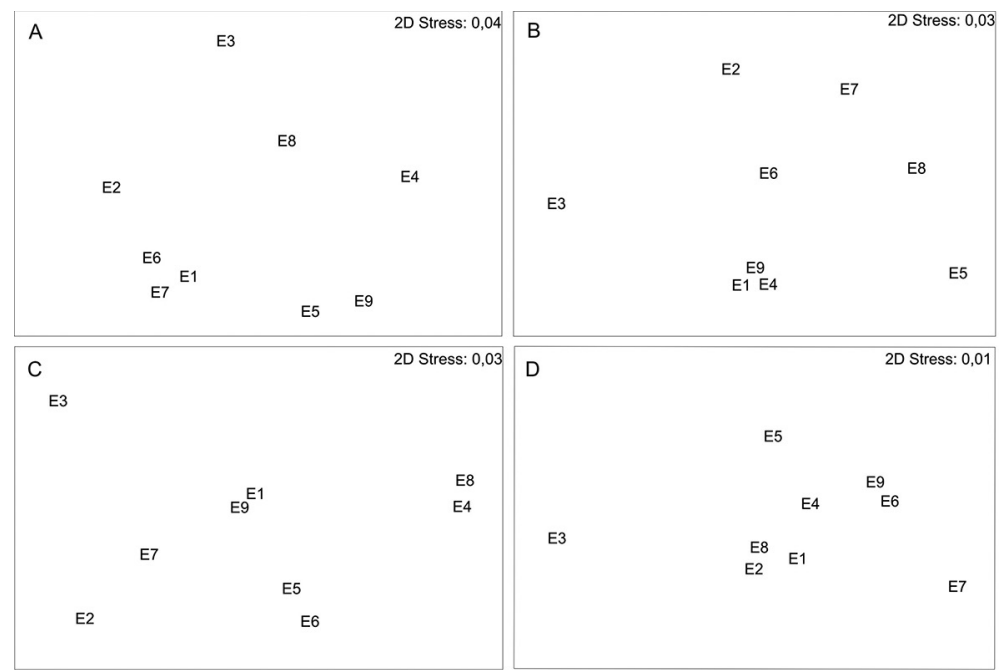

Figure 3. Non-metric multidimensional scaling ordination plot for Budi Lagoon macrobenthos abundance calculated for the four seasons of 2005 (A: summer, B: autumn, C: winter, D: spring).

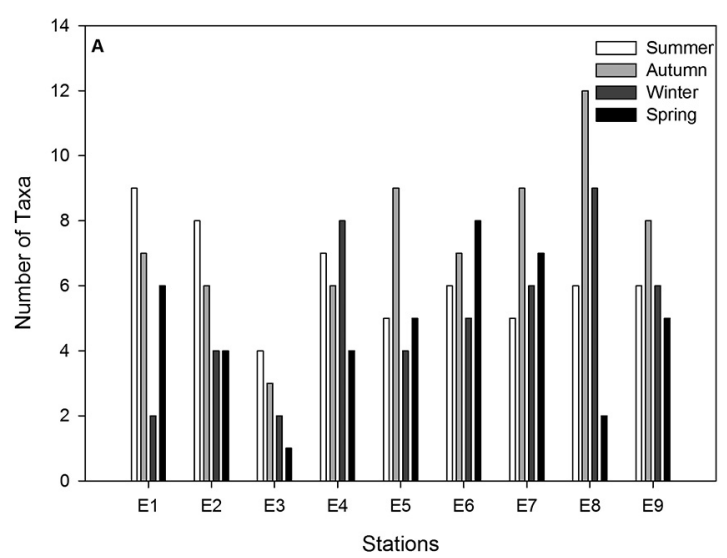

Figure 4A: Number of taxa.

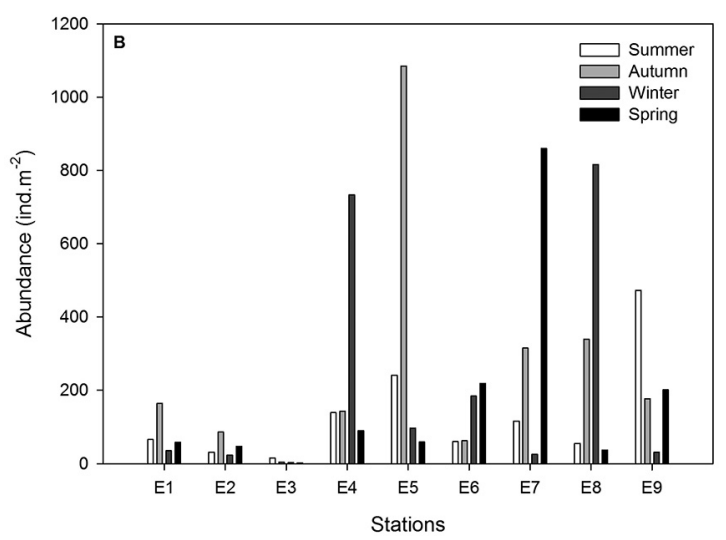

Figure 4B: Abundance.

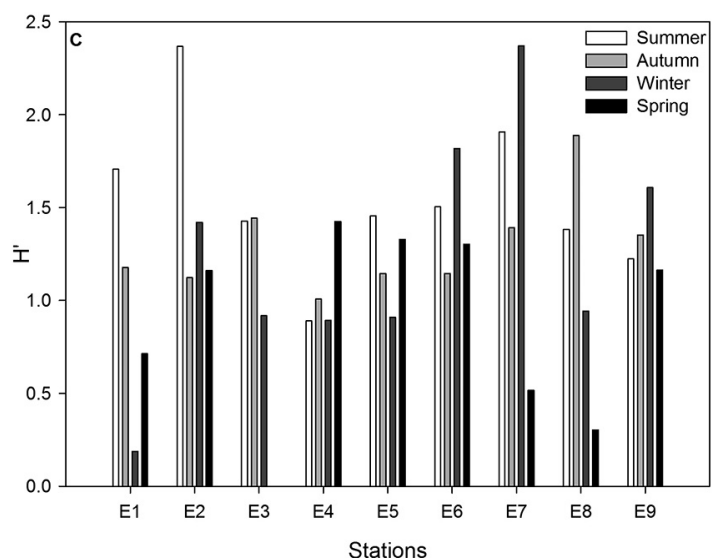

Figure 4C: Shannon-Wiener Diversity $\left(\mathrm{H}^{\prime}\right)$.

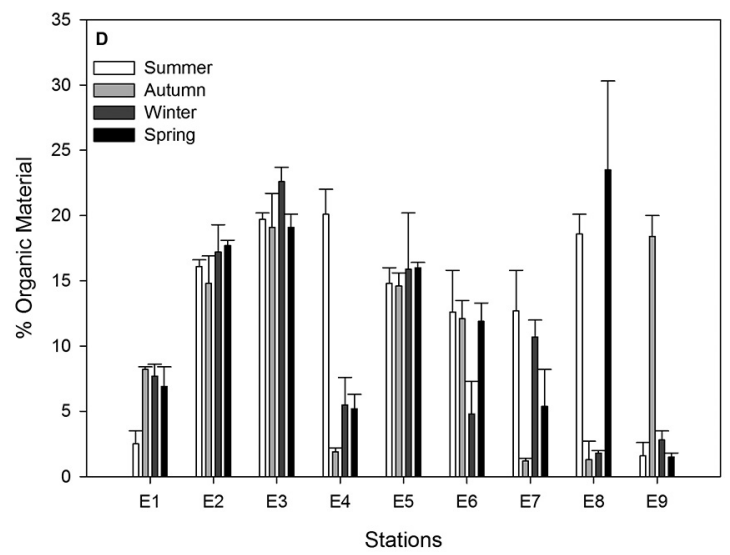

Figure 4D: $\%$ of Organic Material at the nine Budi Lagoon sampling stations, calculated for the four seasons of year. 
al., 2001; JARAMILLO et al., 2001; PEQUEÑO et al., 2010; FIERRO et al., 2014), an ecosystem in which the greatest abundances were found in the summer. One possible reason for this difference is that estuaries are subject to the effects of tides, which periodically create physicochemical variations (BERTRÁN et al., 2010). In contrast, the Budi Lagoon is only connected with the sea during winter. Changes in the salinity of the study area would indirectly affect the macrobenthic communities (ARENAS, 1971; BRAVO, 1984; ENCALADA et al., 2010). Furthermore, agricultural labours near the shoreline increase during summer (BERTRÁN et al., 2010), which could be related to the spatial variation of increased muddy sediment and organic material. In turn, these variations would cause eutrophication in the system, reducing organism diversity and abundance (FIERRO et al., 2012).

The different levels in organic material between the stations may be due to biological interactions, although the effects of anthropic activities near the shore cannot be discounted. Biological interactions were observed at stations E2 and E3, which were located in a sector acting as a habitat for a large number of birds, which, in turn, provided high organic content via faeces. Anthropic activities (e.g. agriculture, forest plantations) also contribute a runoff and considerable increase in sediments with high organic content in coastal zones, mainly as a result of soil erosion (SYVITISKI et al., 2005). This situation was apparent along most of the Budi Lagoon shoreline, where cereals, legumes, and especially potatoes are cultivated (BERTRÁN et al., 2010). The cultivation techniques likely promote the runoff of terrigenous material to the Bondi lagoon.

The variable inputs of terrigenous material into the lagoon sediment could produce the observed differences between sampling stations, in addition to directly influencing the richness and distribution of the macrobenthos. Indeed, FIERRO et al. (2015) demonstrated that the macrobenthos assemblage of streams was altered by different land use practices. In the Bondi Lagoon, there was a strong connection between organic material content and macrobenthos abundance, with higher organic material $(>20 \%)$ related to a decrease in abundance. A high percentage of organic material and the existence of vast sectors of black reducing sediments generate poor conditions for the subsistence of macrobenthic organisms (STUARDO; VALDOVINOS, 1989), as was the situation at stations with a lower number of species and individuals. The agricultural activities near the Budi Lagoon shoreline result in excessive nutrient load inputs, which would consequently cause eutrophication and even episodic crises of anoxia (MCCOMB, 1995; CASTEL et al., 1996).
On the other hand, the organic load recorded for the Budi Lagoon likely facilitated that the most abundant taxa were molluscs and polychaetes. Both taxa were represented, especially by $L$. cumingii (Gastropoda) and P. patagonica (Polichaeta). However, L. cumingii snails were most abundant in sectors with low percentages of organic materials and sandy-muddy sediments. This result contrast that registered by MISTRI et al. (2001) in the Sacca di Goro Lagoon of northeast Italy, who found Hidrobia sp. (Gastropoda) in sectors with substrates characterized by high organic material and slow water movements that favoured sedimentation rates.

In turn, the polychaete $P$. patagonica was abundant in sectors with high organic material content, which can be related to its habits as a detritus feeder (DÍAZJARAMILLO et al., 2008). The Quele River, located near the Bondi Lagoon, also presents high abundances of $P$. patagonica $\left(>140,000\right.$ ind. $\left.\mathrm{m}^{-2}\right)$ in sandy-muddy substrates with not greater than $10 \%$ organic material (QUIJÓN; JARAMILLO, 1993; JARAMILLO et al., 2001). Likewise, FIERRO et al. (2014) registered high polychaete abundances in the Valdivia River estuary, which was probably the result of high organic material quantities in the estuary.

Other species worth mentioning, although present in low densities, were the Diptera of the Chironomidae family. These organisms were found in habitats with high organic content, specifically at stations E2 and E7. These results were similar to those of MISTRI et al. (2001) for the Sacca di Goro Lagoon. Likewise, species were found that are associated with the mixohaline ecosystem, such as K. chilenica, Paracorophium hartmannorum, and the oligochaete Tubifex sp., findings that concur with reports by JARAMILLO et al. (2001) for the Queule River estuary and by FIERRO et al. (2014) for the Valdivia River estuary. These species are somewhat tolerant to organic contamination (FIERRO et al., 2012), which could explain the presence of this taxa in the Bondi Lagoon.

In conclusion, the present results suggest that the low salinity and high organic material input (e.g. resident and migratory bird faeces, abundant aquatic vegetation growth, and nearby agriculture) contribute to excessive nutrients, thereby directly affecting the richness, diversity, distribution, and variation of the Budi Lagoon macrobenthos.

\section{ACKNOWLEDGMENTS}

The authors thank R. Arriagada for helping in field work. This study was made possible through the support of FONDECYT projects 1110798 and 1151375. 


\section{REFERENCES}

ARENAS, J. Distribución de Elminius kingii Gray (Cirr.) en el estuario del río Valdivia. Beitr. Neotrop. Fauna, v. 6, n. 3, p. 199-206, 1971.

ARIAS, A.; DRAKE, P. Structure and production of the benthic macroinvertebrate community in a shallow lagoon in the Bay of Cádiz. Mar. Ecol. Prog. Ser., v. 115, p. 151-167, 1994.

BENEDETTI-CECCHI, L.; RINDI, F.; BERTOCCI, I.; BULLERI, F.; CINELLI, F. Spatial Variation in Development of Epibenthic Assemblages in a Coastal Lagoon. Estuar. Coast. Shelf Sci., v. 52, n. 5, p. 659-668, 2001.

BERTRÁN, C. Zonación y dinámica temporal de la macrofauna intermareal en el estuario del Río Lingue (Valdivia, Chile). Rev. Chil. Hist. Nat., v. 62, p. 19-32, 1989.

BERTRÁN, C.; ARENAS, J.; PARRA, O. Macrofauna del curso inferior y estuario del río Biobío (Chile): cambios asociados a variabilidad estacional del caudal hídrico. Rev. Chil. Hist. Nat., v. 74 , n. 2, p. 331-340, 2001

BERTRÁN, C.; VARGAS-CHACOFF, F.; PEÑA-CORTÉS, F.; MULSOW, S.; TAPIA, J.; HAUENSTEIN, E.; SCHLATTER, R.; BRAVO, A. Macrofauna bentónica de los humedales de tres lagos salinos en el borde costero del sur de Chile. Cien. Mar., v. 32, n. 3, p. 589-596, 2006.

BERTRÁN, C.; VARGAS-CHACOFF, L.; PEÑA-CORTÉS, F.; SCHLATTER, R.; TAPIA, J.; HAUENSTEIN, E. Distribución de la macrofauna bentónica en el lago costero Budi, Sur de Chile. Rev. Biol. Mar. Oceanogr., v. 45, n. 2, p. 235-243, 2010.

BERTRÁN, C.; JIMÉNEZ, C.; FIERRO, P.; PEÑA-CORTÉS, F.; TAPIA, J.; HAUENSTEIN, E.; VARGAS-CHACOFF, L. Alimentación de Micropogonias furnieri (Osteichtyes: Scianidae) en el lago costero Budi, Sur de Chile. Rev. Biol. Mar. Oceanogr., v. 48, n. 1, p. 193-197, 2013.

BEUKEMA, J. J. Expected effects of change in winter temperatures on benthic animals living in soft sediment in coastal North Sea areas. In: BEUKEMA, J. J.; WOLFF W. J., BROUNS, J. J. W. M. (Eds). Expected Effects of climatic Change on Marine Coastal Ecosystems. Dordrecht: Springer Science, 1990. p. 83-92.

BRAVO, A. Distribución de la macrofauna submareal en los fondos blandos de la Bahía Queule y estuario del río Queule. Medio Amb., v. 7, n. 1, p. 37-46, 1984.

BROWER, J.; ZAR, J.; VON ENDE, C. N. Field Laboratory methods for General Ecology. Dubuque: Wm. C. Brown Company Publishers, 1990. 237 p.

BYERS, S. C.; MILLS, E. L.; STEWART, P. L. A comparison of methods to determining organic carbon in marine sediments, with suggestion for a standard method. Hydrobiologia, v. 58, n. 1, p. 43-47, 1978 .

CASTEL, J.; CAUMETTE, P.; HERBERT, R. Eutrophication gradients in coastal lagoons as exemplified by the bassin d'Arcachon and the Étang du Prévost. Hydrobiologia, v. 329, n. 1, p. 9-28, 1996.

CLARKE, K. R.; WARWICK, R. M.; SOMERFIELD, P. J.; GORLEY, R. N. Change in marine communities: an approach to statistical analysis and interpretation. 3rd ed. Plymouth: PRIMER-E Ltd, 2005. 144 p.

CONTRERAS, H.; JARAMILLO, E.; DUARTE, C.; MCLACHLAN, A. Population abundances, growth and natural mortality of the crustacean macrofauna at two sand beach morphodynamic types in southern Chile. Rev. Chil. Hist. Nat., v. 76, n. 4, p. 543-561, 2003.
DIRECCIÓN GENERAL DE AERONÁUTICA CIVIL. (DGAC). Anuario Climatologico 2005. Santiago, 2006. 189 p.

DÍAZ-JARAMILLO, M.; MUÑOZ, P.; DELGADO-BLAS, V.; BERTRÁN, C. Spatio-temporal distribution of spionids (Polychaeta-Spionidae) in an estuarine system in south-central Chile. Rev. Chil. Hist. Nat., v. 81, n. 4, p. 501-514, 2008.

DRAKE, P.; ARIAS, A. M. The effect of aquaculture practices on the benthic macroinvertebrate community of a lagoon system in the Bay of Cadiz (southwestern Spain). Estuaries, v. 20, n. 4, p. 677-688, 1997.

ENCALADA, E.; BERTRÁN, C.; VARGAS-CHACOFF, L. Changes to the benthic assemblage associated with mollusc and seaweed cultivation in the Quempillén estuary, north Patagonia, Chile. Gayana (Concepc.), v. 74, n. 2, p. 147-151, 2010.

FIERRO, P.; BERTRÁN, C.; MERCADO, M.; PEÑA-CORTÉS, F.; TAPIA, J.; HAUENSTEIN, E.; VARGAS-CHACOFF, L. Benthic macroinvertebrate assemblages as indicators of water quality applying a modified biotic index in a spatio-seasonal context in a coastal basin of Southern Chile. Rev. Biol. Mar. Oceanogr., v. 47, n. 1, p. 23-33, 2012.

FIERRO, P.; BERTRÁN, C.; MARTINEZ, D.; VALDOVINOS, C.; VARGAS-CHACOFF, L. Ontogenetic and temporal changes in the diet of the Chilean silverside Odontesthes regia (Atherinidae) in southern Chile. Cah. Biol. Mar., v. 55, n. 3, p. 323-332, 2014.

FIERRO, P.; BERTRÁN, C.; MERCADO, M.; PEÑA-CORTÉS, F.; TAPIA, J.; HAUENSTEIN, E.; CAPUTO, L.; VARGASCHACOFF, L. Landscape composition as a determinant of diversity and functional feeding groups of aquatic macroinvertebrates in southern rivers of the Araucanía, Chile. Lat. Am. J. Aquat. Res., v. 43, n. 1, p. 186-200, 2015.

FOLK, R. L. Petrology of sedimentary rocks. Austin: Hemphill, 1980. $184 \mathrm{p}$.

GALLARDO, C. S. Reproductive habits and life cycle of the small clam Kingiella chilenica (Bivalvia: Cyamiidae) in an estuarine sand flat from the South of Chile. Mar. Biol., v. 115, n. 4, p. 595-603, 1993.

GLÉMAREC, M. Ecological impact of an oil spill: utilization of biological indicators. Water Sci. Technol., v. 18, n. 4/5, p. 203$211,1986$.

HOLLAND, A. F.; SHAUGHNESSY, A. T.; HIEGEL, M. H. Longterm variation in mesohaline Chesapeake bay macrobenthos: Spatial and temporal patterns. Estuaries, v. 10, n. 3, p. 227-245, 1987.

HYNES, H. B. N. The ecology of running waters. Liverpool: Liverpool University Press, 1970. 555 p.

JARAMILLO, E.; MULSOW, S.; PINO, M.; FIGUEROA, H. Subtidal benthic macrofauna in an estuary of south of Chile: distribution pattern in relation to sediment types. Mar. Ecol., v. 5, n. 2, p. 119-133, 1984.

JARAMILLO, E.; CONTRERAS, H.; QUIJÓN, P. Variabilidad estacional e interanual en las abundancias poblacionales de la macrofauna intermareal del estuario del río Queule, centro-sur de Chile. Rev. Chil. Hist. Nat., v. 74, n. 2, p. 455-468, 2001.

KALEJTA, B.; HOCKEY, P. A. R. Distribution, abundance and productivity of benthic invertebrates at the Berg River estuary, South Africa. Estuar. Coast. Shelf Sci., v. 33, n. 2, p. 175-191, 1991.

KJERFVE, B. Coastal lagoon processes. Amsterdam: Elsevier, 1994. 
MCCOMB, A. J. Eutrophic shallow estuaries and lagoons. Boca Raton: CRC Press, 1995. 252 p.

MISTRI, M.; ROSSI, R.; FANO, E. A. Structure and Secondary Production of a Soft Bottom Macrobenthic Community in a Brackish Lagoon (Sacca di Goro, north-eastern Italy). Estuar. Coast. Shelf Sci., v. 52, n. 5, p. 605-616, 2001.

NICHOLS, F. H.; CLOERN, J. E.; LUOMA, S. N.; PETERSON, D. H. The modification of an estuary. Science, v. 231, n. 4738, p. 567-573, 1986.

PEQUEÑO, G.; PAVÉS, H.; BERTRÁN, C.; VARGASCHACOFF, L. Seasonal limnetic feeding regime of the "robalo" Eleginops maclovinus (Valenciennes 1830), in the Valdivia river, Chile. Gayana (Concepc.), v. 74, n. 1, p. 47$56,2010$.

PEÑA-CORTÉS，F.; GUTIÉRREZ，P.; REBOLLEDO, G.; ESCALONA, M.; HAUENSTEIN, E.; BERTRÁN, C.; SCHLATTER, R.; TAPIA, J. Determinación del nivel de antropización de humedales como criterio para la planificación ecológica de la cuenca del lago Budi, IX Región de La Araucanía, Chile. Rev. Geogr. Norte Gd., n. 36, 75-91, $2006 \mathrm{a}$.

PEÑA-CORTÉS F.; REBOLLEDO, G.; HERMOSILLA, K.; HAUENSTEIN, E.; BERTRÁN, C.; SCHLATTER, R.; TAPIA, J. Dinámica del paisaje para el período 1980-2004 en la cuenca costera del Rio-Lago Budi, Chile. Consideraciones para la conservación de sus humedales. Ecol. Austral, v. 16, n. 2, p. 183-196, 2006b.

PEÑA-CORTÉS, F.; PINCHEIRA-ULBRICH, J.; BERTRÁN, C.; TAPIA, J.; HAUENSTEIN, E.; FERNÁNDEZ, E.; ROZAS, D. A study of the geographic distribution of swamp forest in the coastal zone of the Araucanía Region, Chile. Appl. Geogr., v. 31, n. 2, p. 545-555, 2011.
PÉREZ-RUZAFA, A.; MARCOS, C.; PÉREZ-RUZAFA, I. M.; PÉREZ-MARCOS, M. Coastal lagoons: "transitional ecosystems" between transitional and coastal waters. J. Coast. Conservat., v. 15, n. 3, p. 369-392, 2011.

QUIJÓN, P.; JARAMILLO, E. Temporal Variability in the Intertidal Macroinfauna in the Queule River Estuary, Southcentral Chile. Estuar. Coast. Shelf Sci., v. 37, n. 6, p. 655-667, 1993.

SFRISO, A.; BIRKEMEYER, T.; GHETTI, P. F. Benthic macrofauna changes in areas of Venice lagoon populated by seagrasses or seaweeds. Mar. Environ. Res., v. 52, n. 4, p. 323-349, 2001.

STONER, A. W.; ACEVEDO, C. The macrofaunal community of a tropical estuarine lagoon. Estuaries, v. 13, n. 2, p. 174$181,1990$.

STUARDO, J.; VALDOVINOS, C. Estuarios y lagunas costeras: ecosistemas importantes de Chile central. Amb. Des., v. 5, n. 1, p. 107-115, 1989.

SYVITSKI, J. P.; VÖRÖSMARTY, C. J.; KETTNER, A. J.; GREEN, P. Impact of humans on the flux of terrestrial sediment to the global coastal ocean. Science, v. 308, n. 5720, p. 376-380, 2005.

UNDERWOOD, A. J.; CHAPMAN, M. G. Scales of spatial patterns of distribution of intertidal invertebrates. Oecologia, v. 107, n. 2 , p. $212-224,1996$ 